\title{
Effect of FSH and insulin on lipogenesis in cultures of Sertoli cells from immature rats
}

F.C.R. Guma ${ }^{1}$, M. Wagner ${ }^{2}$, L.H. Martini ${ }^{1}$ and E.A. Bernard ${ }^{1}$

\author{
1Departamento de Bioquímica and \\ ${ }^{2}$ CPG Fisiologia, Instituto de Biociências, \\ Universidade Federal do Rio Grande do Sul, \\ 90046-900 Porto Alegre, RS, Brasil
}

\footnotetext{
Correspondence

F.C.R. Guma

Departamento de Bioquímica

IB, UFRGS

Rua Sarmento Leite, 500/212

90046-900 Porto Alegre, RS

Brasil

Fax: 55 (051) 227-1343

E-mail: fguma@vortex.ufrgs.br

Research supported by FINEP, CNPq, and FAPERGS.
}

Received June 27, 1996 Accepted January 29, 1997

\begin{abstract}
Follicle-stimulating hormone (FSH) and insulin regulate glycide metabolism in Sertoli cells, thus stimulating lactate production. These stimulatory effects of FSH and insulin do not require protein synthesis, suggesting a modulation of enzyme activity and/or regulation of glucose transport. The present investigation was performed to characterize the hormonal control of lipid metabolism in Sertoli cells. The data indicate that FSH and insulin have a regulatory effect on lipid metabolism in Sertoli cells. After $8 \mathrm{~h}$ of preincubation with insulin (5 $\mu \mathrm{g} / \mathrm{ml}$ ), the activity of the enzyme ATP-citrate lyase in cultured Sertoli cells was increased from 0.19 to $0.34 \mathrm{nmol} \mathrm{NAD}^{+}$formed $\mu \mathrm{g}$ protein ${ }^{-1}$ $\mathrm{min}^{-1}$. FSH $(100 \mathrm{ng} / \mathrm{ml})$ had no effect on this enzyme. Glycerol phosphate dehydrogenase activity was not affected by any of the hormones tested. When Sertoli cells from 19-day old rats were incubated with $\left[1,2-{ }^{14} \mathrm{C}\right]$ acetate for 90 or $360 \mathrm{~min}$, the $\left[{ }^{14} \mathrm{C}\right]$ label was present predominantly in triglyceride and phospholipid fractions with minor amounts in other lipids. In Sertoli cells pretreated for $16 \mathrm{~h}$ with insulin and FSH, an increase in acetate incorporation into lipids was observed. Most of the label was in esterified lipids and this percentage increased with the time of treatment; this increase was remarkable in triglycerides of control cells (18.8\% to $30.6 \%$ ). Since Sertoli cell triglycerides participate in the control of spermatogenesis, the present data suggest that the hormonal control of lipid metabolism in Sertoli cells is important not only for maintaining the energy of the cell itself, but also for the control of the spermatogenesis process.
\end{abstract}

Key words

- Sertoli cells

- Lipids

- FSH

- Insulin

\section{Introduction}

Testicular lipids have an active metabolism, and are formed both from dietary sources and as the result of processes of synthesis, elongation, desaturation, interconversion, esterification and oxidation by testicular tissue. Testicular tissue has the full complement of cytosolic enzymes required for de novo syn- thesis of fatty acids. Various factors have been shown to alter the lipid composition of the testis. Testicular lipids generally increase in concentration with development. Nutritional factors such as inanition, vitamin deficiency, essential fatty acid deficiency and certain mineral deficiencies affect the testicular lipid composition (1). Treatment with thyroid hormone, prolactin or progesterone causes a decrease in 
rat testicular lipids. Both protein and vitamin A deficiencies in 21-day old rats resulted in decreased testis weight along with decreased amounts of phospholipid fraction containing phosphatidylserine and inositol (1).

The metabolism of $\left[{ }^{14} \mathrm{C}\right]$ palmitic acid in primary cultures of rat Sertoli cells isolated from testes of 19-day old rats has been reported (2). The oxidation of palmitate was concentration dependent. About $65 \%$ of palmitate oxidation over a 5 -h period was recovered as carbon dioxide. Almost all radioactive soluble compounds secreted by Sertoli cells were either $\mathrm{B}-\mathrm{OH}$ butyrate or acetoacetate. The addition of glucose had no effect on palmitate oxidation but caused a 9fold increase in esterification into triacylglycerols. The authors concluded that fatty acids appear to be a major energy substrate for Sertoli cells (2).

The metabolism of oleate in isolated rat testicular cells was investigated by Yount and Harris (3). The rates of oxidation of oleate to carbon dioxide were higher in cells preparared from immature rats than in cells from adults. In cells from young but not from adult rats, oleate inhibited the oxidation of glucose to carbon dioxide. The authors suggested that lipids may be an important source of energy for the prepubertal rat testis, but the major source of energy for the adult rat testis appeared to be glucose.

The metabolism of linoleic, arachidonic and 22:5n-6 acids in Sertoli cells and germinal cells was compared by Beckman and Coniglio (4). Following an intraperitoneal injection of labeled 22:5n-6 fatty acids a greater proportion of the recovered $\left[{ }^{14} \mathrm{C}\right]$ in Sertoli cells, rather than in germinal cells, was present in 20 -carbon fatty acids, indicating that the metabolism of the pentaene was more active in Sertoli cells than in germinal cells. In both cell types more of the recovered $\left[{ }^{14} \mathrm{C}\right]$ was in triacylglycerols during the early periods and in phospholipids after $24 \mathrm{~h}$, suggesting the possibility of the transfer of the biosynthesized pentaene from Sertoli to germinal cells using triacylglycerols as transfer vehicle $(5,6)$.

The metabolism of Sertoli cells is under the complex control of hormones, growth factors and even paracrine, autocrine and juxtacrine reactions occurring between the various cell types in the testis. The hormonal control of glycide metabolism in Sertoli cells is well known. In immature rats, folliclestimulating hormone (FSH) regulates the production of lactate, a preferential energy substrate for pachytene spermatocytes and round spermatids $(7,8)$. Oonk et al. (9) showed that insulin increases the rate of lactate production in vitro. This effect is obtained with low insulin concentrations and is mediated by insulin-specific receptors existing on Sertoli cells (10). In a comparative study, Oonk et al. (9) showed that the stimulatory effects of FSH and insulin on lactate production do not require the synthesis of new proteins, suggesting a modulation at the level of the activity of enzymes involved in carbohydrate metabolism and/or in glucose transport regulation $(9,11)$.

In view of the importance of lipids in spermatogenesis and the role of Sertoli cells in the seminiferous epithelium, the objective of the present study was to investigate how the hormones FSH and insulin act on lipid metabolism in cultures of Sertoli cells from immature rats.

\section{Material and Methods}

FSH (ovine, NIADDK-oFSH-17, specific activity $20 \mathrm{U} / \mathrm{mg}$ ) was a gift from NIH, Bethesda, Maryland. Insulin (bovine pancreas) was purchased from Sigma Chemical Co. and $\left[1,2-{ }^{14} \mathrm{C}\right]$ acetate (specific activity $54.7 \mathrm{mCi} /$ mmol) was from New England Nuclear (Wilmington, DE). All other chemicals were reagent grade.

\section{Culture of Sertoli cells}

Sertoli cells were prepared from 19-day old Wistar rats according to the procedure of 
Dorrington and Fritz (12). A small percentage (3-4\%) of contaminating peritubular cells, indicated by the histochemical demonstration of alkaline phosphatase activity (13), was present in these Sertoli cell preparations. Cells were plated $\left(2.4 \times 10^{5}\right.$ cells $/ \mathrm{cm}^{2}$, $6 \times 10^{6}$ cells $/ 25 \mathrm{~cm}^{2}$ culture flask) onto 199 medium supplemented with $1 \%$ fetal calf serum and kanamycin $(100 \mathrm{mg} / \mathrm{l})$ under an atmosphere of $5 \% \mathrm{CO}_{2}$ in air at $34^{\circ} \mathrm{C}$. After $24 \mathrm{~h}$ the cellular monolayer was washed and fresh medium was added. On the 3rd day after plating, Sertoli cell cultures were incubated in the presence or absence of FSH (100 $\mathrm{ng} / \mathrm{ml})$ or insulin $(5 \mu \mathrm{g} / \mathrm{ml})$.

\section{Cell labeling and lipid extraction}

After the exposure of the cells to hormones the medium was changed and the incubations were continued for 90-360 min in the presence of $\left[1,2-{ }^{14} \mathrm{C}\right]$ acetate $(1 \mu \mathrm{Ci} /$ $\mathrm{ml})$. At the end of the incubation the cells were washed with PBS, scraped in PBS and sonicated $(2 \times 30 \mathrm{~s}, 40 \mathrm{~mA})$. An aliquot was used for protein determination (14) and the rest for lipid extraction according to the procedure of Folch et al. (15). An aliquot of the extract was counted for radioactivity. The rest was applied to silica gel plates and chromatographed in hexane:diethyl ether: acetic acid (80:20:2, by volume). After development, the plates were subjected to autoradiography (X-OMAT, Kodak) for localization of radiolabeled areas. The lipid bands were scraped directly from the plates into liquid scintillation vials and counted. The standard lipids were located by exposing the plates to iodine vapor.

\section{Enzyme assay}

Sertoli cells were incubated for 8 or $24 \mathrm{~h}$ with FSH $(100 \mathrm{ng} / \mathrm{ml})$ or insulin $(5 \mu \mathrm{g} / \mathrm{ml})$ for the determination of ATP-citrate lyase activity by the method of Mackall et al. (16). Briefly, after hormonal treatment the cells were collected and sonicated $(2 \times 30 \mathrm{~s}, 40$ $\mathrm{mA}$ ) in $20 \mathrm{mM}$ Tris- $\mathrm{HCl}$ buffer, $\mathrm{pH} 8.0$, containing 1 mMEDTA, 1 mM dithiothreitol and $0.25 \mathrm{mM}$ sucrose. Enzyme activity was determined in the $20,000 \mathrm{~g}$ supernatant solution. The incubation system contained potassium citrate, NADH and malate dehydrogenase. ATP-citrate lyase activity was determined by coupling with the malate dehydrogenase reaction. Gycerol phosphate dehydrogenase activity was determined by the method of Wise and Green (17). As also done for ATP-citrate lyase, the cells were collected and sonicated after hormonal treatment using $50 \mathrm{mM}$ Tris- $\mathrm{HCl}$ buffer, $\mathrm{pH} 7.5$, containing $1 \mathrm{mM}$ EDTA and $1 \mathrm{mM}$ mercaptoethanol. The activity was also determined in the 20,000 $g$ supernatant solution using dihydroxyacetone phosphate and NADH as substrates. An aliquot of each supernatant was used for protein determination (14).

\section{Statistical analysis}

Differences among the experimental groups were analyzed by two-way analysis of variance. Means were compared by the Newman-Keuls test.

\section{Results}

\section{Determination of the effect of FSH and insulin on ATP-citrate lyase and glycerol phosphate dehydrogenase activity}

As the first approach to the study of lipid metabolism in Sertoli cells, we determined the effect of FSH and insulin on two enzymes that act on lipid synthesis. The results listed in Table 1 show that ATP-citrate lyase was stimulated when the cells were treated for $8 \mathrm{~h}$ with insulin. A more prolonged treatment $(24 \mathrm{~h})$ with insulin did not alter the activity of the enzyme, butFSH had no effect at any of the times tested. Glycerol phosphate dehydrogenase activity was not modified by either hormone. ATP-citrate lyase 
Table 1 - Effect of FSH and insulin on ATP-citrate lyase and glycerol phosphate dehydrogenase specific activity of Sertoli cells.

Data are reported as specific activity (nmol NAD ${ }^{+}$formed $\mu$ g protein $\left.{ }^{-1} \mathrm{~min}^{-1}\right)$. Sertoli cells from 19-day old rats were treated with medium containing FSH $(100 \mathrm{ng} / \mathrm{ml})$ or insulin $(5 \mu \mathrm{g} / \mathrm{ml})$ for 8 and $24 \mathrm{~h}$. The cultures used in the 8- and 24-h experiments were from different preparations. Enzyme activity was measured for $15 \mathrm{~min}$ at $37^{\circ} \mathrm{C}$. Data are reported as the mean \pm SEM of 6 determinations. ${ }^{*} \mathrm{P}<0.05$ compared to control and FSH (Newman-Keuls test).

\begin{tabular}{lccccc}
\hline & \multicolumn{2}{c}{ ATP-citrate lyase } & & \multicolumn{2}{c}{ Glycerol phosphate dehydrogenase } \\
\cline { 2 - 3 } \cline { 5 - 6 } & $8 \mathrm{~h}$ & $24 \mathrm{~h}$ & & $8 \mathrm{~h}$ & $24 \mathrm{~h}$ \\
\hline Control & $0.19 \pm 0.04$ & $0.21 \pm 0.02$ & & $1.30 \pm 0.07$ & $1.19 \pm 0.04$ \\
FSH & $0.23 \pm 0.01$ & $0.17 \pm 0.01$ & & $1.38 \pm 0.11$ & $1.09 \pm 0.04$ \\
Insulin & $0.34 \pm 0.01^{*}$ & $0.34 \pm 0.01^{*}$ & & $1.33 \pm 0.06$ & $1.02 \pm 0.05$
\end{tabular}

activity in Sertoli cell cultures was very low (about $0.20 \mathrm{nmol} \mathrm{NAD}^{+}$formed $\mu \mathrm{g}$ protein ${ }^{-1}$ min $^{-1}$ ), i.e., approximately 10 times lower than that demonstrated in the epididymis of rats of the same age $\left(2.3 \pm 0.05 \mathrm{nmol} \mathrm{NAD}^{+}\right.$ formed $\mu$ g protein ${ }^{-1} \mathrm{~min}^{-1}$ ). Activity levels as low as those reported here for Sertoli cells have been reported by Brown et al. (18) in the rat testis.

\section{$\left[{ }^{14} \mathrm{C}\right]$ acetate incorporation}

The next step was to determine the kinetics of radioactive acetate incorporation into lipids and to investigate the effects of FSH and insulin on this incorporation. Table 2 shows that both FSH and insulin significantly stimulated acetate incorporation into Sertoli cells and that this effect was related to time of incubation.

We then determined the distribution of the radioactive label among the different lipid classes using two parameters, i.e., time and hormone effect. Table 3 compares two different times of incubation with acetate in each experimental situation, and Figure 1 presents a comparison of the action of the two hormones. Analysis of Table 3 shows that, as early as after 90 min of incubation with acetate, approximately $70 \%$ of the label was distributed among triglycerides (TG)
Table 2 - Effect of FSH and insulin on $\left[1,2-{ }^{14} \mathrm{C}\right]$ acetate incorporation into Sertoli cell lipids.

Sertoli cells were pretreated for $16 \mathrm{~h}$ with $100 \mathrm{ng} /$ $\mathrm{ml} \mathrm{FSH}$ or $5 \mu \mathrm{g} / \mathrm{ml}$ insulin and incubated for $90 \mathrm{~min}$ with $1 \mu \mathrm{Ci} / \mathrm{ml}$ and for $360 \mathrm{~min}$ with $0.5 \mu \mathrm{Ci} / \mathrm{ml}[1,2-$ ${ }^{14} \mathrm{C}$ lacetate. Data are reported as the mean \pm SEM of 6 determinations. ${ }^{*} P<0.05$ compared to control; $+P<0.05$ compared to control and FSH (Newman-Keuls test).

\begin{tabular}{lcc}
\hline & {$\left[1,2-{ }^{14}\right.$ Clacetate (cpm/ $\mu$ p protein) } \\
\cline { 2 - 3 } & $90 \mathrm{~min}$ & $360 \mathrm{~min}$ \\
\hline Control & $23.2 \pm 0.8$ & $26.9 \pm 3.4$ \\
FSH & $26.7 \pm 1.3^{*}$ & $77.1 \pm 6.5^{*}$ \\
Insulin & $28.3 \pm 0.9^{*}$ & $52.8 \pm 5.4^{+}$
\end{tabular}

and phospholipids (PL), and the remaining $30 \%$ was distributed among free fatty acids (FA), monoglycerides (MG), diglycerides (DG) and cholesterol (C). In 360-min incubations, the same radioactive compounds appeared with slight percent alterations, showing a possible migration of the radioactive label from FA, MG and DG to TG.

Incorporation into cholesterol was always very low and decreased with time, and the incorporation into cholesterol ester was negligible.

\section{Action of $\mathrm{FSH}$ and insulin on $\left[{ }^{14} \mathrm{C}\right]$ acetate incorporation}

Besides determining how the distribution of radioactivity incorporated into lipids is affected by time of incubation with $\left[{ }^{14} \mathrm{C}\right]$ acetate, we compared the action of FSH and insulin. The cells were preincubated with FSH or insulin for $16 \mathrm{~h}$ and incubated with acetate for the same times as described above. Analysis of Figure 1A and 1B shows that treatment with the hormones did not change the distribution profile of radioactivity described above for the controls (Table 3). In cells treated with insulin, after 90 to $360 \mathrm{~min}$ of incubation with the precursor, the transfer of the radioactive label from FA, MG and DG to TG was similar to that observed in the 
Table 3 - Effect of time of incubation with $\left[1,2-{ }^{14}\right.$ C $]$ acetate $(90$ or $360 \mathrm{~min}$ ) on Sertoli cells in culture pretreated with $\mathrm{FSH}$ or insulin for $16 \mathrm{~h}$ and on control cells.

The results are reported as percent total incorporation of radioactivity into lipids in Sertoli cell cultures. Sertoli cells were pretreated for $16 \mathrm{~h}$ with FSH or insulin and incubated for $90 \mathrm{~min}$ with $1 \mu \mathrm{Ci} / \mathrm{ml}$ and for $360 \mathrm{~min}$ with $0.5 \mu \mathrm{Ci} / \mathrm{ml}\left[1,2-{ }^{14} \mathrm{C}\right]$ acetate. The lipid extract was chromatographed and the radioactivity in lipid bands counted. Data are reported as the mean \pm SEM of 6 determinations. ${ }^{*} \mathrm{P}<0.05$ compared to 90 -min incubation time (Newman-Keuls test).

\begin{tabular}{|c|c|c|c|c|c|c|}
\hline & \multicolumn{2}{|c|}{ Control } & \multicolumn{2}{|c|}{ FSH } & \multicolumn{2}{|c|}{ Insulin } \\
\hline & $90 \mathrm{~min}$ & $360 \mathrm{~min}$ & $90 \mathrm{~min}$ & $360 \mathrm{~min}$ & $90 \mathrm{~min}$ & $360 \mathrm{~min}$ \\
\hline Phospholipds & $50.8 \pm 2.1$ & $54.1 \pm 1.4$ & $48.6 \pm 2.9$ & $49.3 \pm 0.9$ & $47.3 \pm 1.1$ & $50.7 \pm 1.4^{*}$ \\
\hline Cholesterol & $3.8 \pm 0.1$ & $2.1 \pm 0.1^{*}$ & $1.6 \pm 0.01$ & $2.1 \pm 0.01 *$ & $2.9 \pm 0.01$ & $2.8 \pm 0.01$ \\
\hline Fatty acids & $10.3 \pm 0.7$ & $1.4 \pm 0.1^{*}$ & $5.4 \pm 0.7$ & $1.0 \pm 0.01^{*}$ & $5.3 \pm 0.01$ & $0.8 \pm 0.01 *$ \\
\hline Monoglycerides & $4.2 \pm 0.1$ & $2.0 \pm 0.1^{*}$ & $5.6 \pm 2.4$ & $2.4 \pm 1.4^{*}$ & $2.8 \pm 0.01$ & $1.7 \pm 0.01 *$ \\
\hline Diglycerides & $8.2 \pm 0.7$ & $4.2 \pm 0.1^{*}$ & $10.7 \pm 1.2$ & $4.2 \pm 0.7^{*}$ & $12.9 \pm 0.5$ & $9.0 \pm 0.7^{*}$ \\
\hline Triglycerides & $18.8 \pm 1.7$ & $30.6 \pm 1.7^{*}$ & $24.6 \pm 1.7$ & $38.9 \pm 1.4^{*}$ & $24.9 \pm 0.5$ & $30.3 \pm 0.7^{*}$ \\
\hline
\end{tabular}

controls. Nevertheless, there was a significant increase in TG labeling after FSH treatment. The two hormones also provoked a decrease in the amount of radioactivity incorporated into PL compared to the controls (Figure 1B). These effects are more clearly visualized in Table 3 which shows the distribution of the radioactive label among cells treated with insulin and FSH at the two times of incubation with acetate. FSH induced an increase in the transfer of radioactivity only to TG, and insulin had the same effect, although of lower magnitude, on TG and PL. FSH also induced a slight increase in the levels of cholesterol.

\section{Discussion}

The present data show that both FSH and insulin significantly stimulated acetate incorporation into Sertoli cells from prepubertal rats and that this effect was related to time of incubation (Table 2). The effect of insulin on lipid synthesis was obtained with concentrations above physiological range (the normal insulin concentration in peripheral circulation is $0.5 \mathrm{ng} / \mathrm{ml}(100 \mathrm{pM})$ in fasted animals), and may reflect binding of insulin to insulin receptors or to receptors for insulin-like growth factor I (IGF-I). Borland et al. (19) also reported that micromolar concentrations of insulin were required to obtain a small stimulatory effect on lactate production, and DNA and protein synthesis by Sertoli cells from 2-week old rats.

Table 3 shows that after 90 min of incubation with $\left[{ }^{14} \mathrm{C}\right]$ acetate, $70 \%$ of the radioactivity incorporated into lipids was simultaneously present in TG and PL. This percentage was still higher after $360 \mathrm{~min}$ of incubation with the precursor (Table 3). On the basis of the comparison of the rate of acetate incorporation with the low levels of ATPcitrate lyase activity (Table 1) detected in Sertoli cells, we suggest that these cells utilize acetate for lipid synthesis without the involvement of mitochondria. This may indicate that the testes take up circulating acetate in vivo and utilize it directly via a cytoplasmic acetyl-CoA synthetase for fatty acid synthesis. This is possible because of the considerable amounts of acetate existing in rat blood, most of it produced by the intestinal microbial flora (20).

Aveldaño et al. (6) incubated seminiferous tubules from 6-week old rats with $\left[{ }^{14} \mathrm{C}\right]$ acetate and observed that, after $1 \mathrm{~h}$, radioactivity appeared mainly in TG and PL. Between 1 to $4 \mathrm{~h}$ there was a decrease in the radioactivity detected in TG (49 to 41\%). Simi- 
lar results obtained by Fisher and Coniglio (21) in cultures of Sertoli cells from 35-day old rats showed that after $24 \mathrm{~h}$ of incubation with $\left[{ }^{14} \mathrm{C}\right]$ acetate most of the radioactivity was in esterified lipids (TG and PL).

The role of Sertoli cells in the seminiferous epithelium requires a carefully controlled metabolism. Sertoli and germ cells interact in environmental, nutritional and regulatory terms. Some investigators have shown that glucose may not be energetically important for Sertoli cells. The amount of glucose oxidized to $\mathrm{CO}_{2}$ is only a small fraction of the metabolized glucose, while most of it is transformed into pyruvate and lactate (22), which
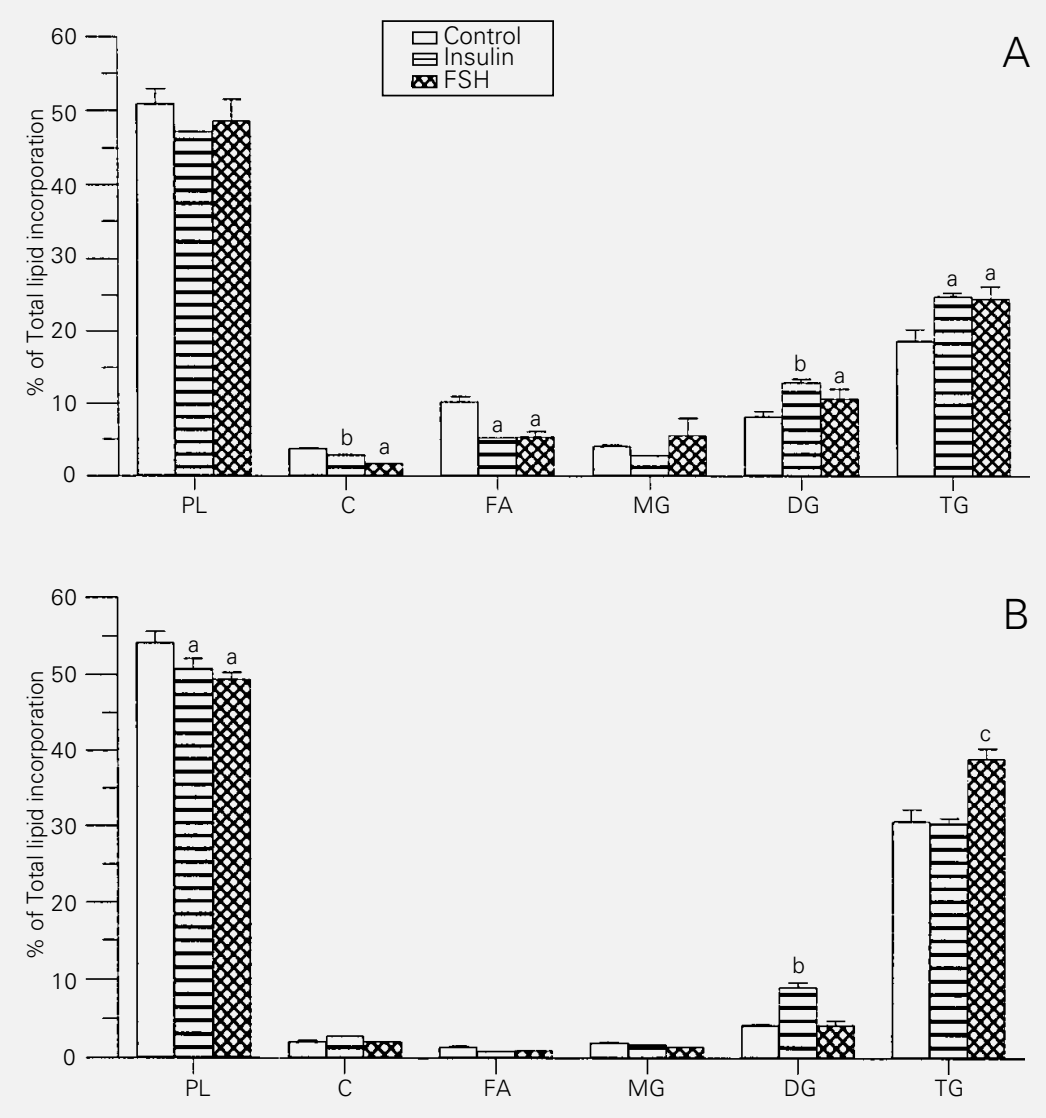

Figure 1-Effects of FSH and insulin on [1,2-14 C]acetate incorporation into classes of lipids of Sertoli cells. Sertoli cells were pretreated for $16 \mathrm{~h}$ with $100 \mathrm{ng} / \mathrm{ml} \mathrm{FSH}$ or $5 \mu \mathrm{g} / \mathrm{ml}$ insulin and incubated for $90 \mathrm{~min}$ with $1 \mu \mathrm{Ci} / \mathrm{ml}$ and for $360 \mathrm{~min}$ with $0.5 \mu \mathrm{Ci} / \mathrm{ml}\left[1,2-{ }^{14} \mathrm{C}\right]$ acetate. $A, 90$ min of acetate treatment; $B, 360$ min of acetate treatment. Data are reported as the mean \pm SEM of 6 determinations. aP $<0.05$ compared to control; $\mathrm{b} P<0.05$ compared to control and FSH; $C P<0.05$ compared to control and insulin. (Newman-Keuls test). PL, Phospholipids; $C$, cholesterol; FA, fatty acids; MG, monoglycerides; DG, diglycerides; TG, triglycerides. are the preferred energy substrates for spermatocytes and spermatids (8). FSH stimulates the production of these compounds. Oonk et al. (9) showed that after $3 \mathrm{~h}$ of incubation FSH or insulin stimulates lactate production in cultures of Sertoli cells. Jutte et al. (7) demonstrated that Sertoli cells survive for as long as $24 \mathrm{~h}$ in glucose-free medium whereas germ cells degenerate.

An indication that lipids may be a more important energy substrate than glucose for Sertoli cells was provided by Jutte et al. (2) who showed that Sertoli cells oxidize palmitate in a concentration-dependent manner and that the addition of glucose to the incubation system does not change palmitate oxidation but causes a 9-fold increase in palmitate esterification to TG, probably due to an increase in glycerol-3-phosphate levels. Fisher and Coniglio (21) demonstrated that the amount of radioactivity in the TG of Sertoli cells was constant between 24 and 48 $\mathrm{h}$ but was decreased in PL, suggesting a higher FA turnover in PL than in TG.

In the present study we showed that a high incorporation of radioactivity into complex lipids (TG and PL) occurred in all experimental situations with increasing time of incubation with acetate (Table 1). Figure 1 shows that a percent increase of acetate incorporation into PL occurred from 90 to $360 \mathrm{~min}$ while the increased incorporation into TG was proportionally higher only in control cells.

Morphologic studies of Sertoli cells have shown that the amount of fat droplets containing TG changes according to the different stages of the spermatogenesis cycle and with different hormonal regimens in vivo (23). Aveldaño et al. (6) reported that the triglycerides of Sertoli cells have a high level of polyunsaturated long-chain fatty acids, and Beckman and Coniglio (4) demonstrated that Sertoli cells are more active than germ cells in the synthesis of these compounds. These authors also proposed that these polyunsaturated acids may be transferred to germ cells and that TG may act as transfer vehicle. 
As early as 1969, Collins and Lacy (23) reported that the amount of lipid droplets in Sertoli cells increased in the presence of damage to the seminiferous epithelium because the germ cells no longer consumed lipids as they usually did.

These facts indicate that, in addition to having a function as an energy substrate, the TG of Sertoli cells may be involved in the maintenance of spermatogenesis. This hypothesis is supported by the results of Beckman and Coniglio (4) who demonstrated that polyunsaturated fatty acid deficiency provokes the interruption of spermatogenesis. Our results showing that FSH and insu- lin stimulate the process of lipid esterification in Sertoli cells permit us to state that the two hormones modulate lipid metabolism in Sertoli cells. On the basis of our results and of those reported by others, we suggest that the control of lipid metabolism in Sertoli cells is important not only for maintaining the energy of the cell itself, but also for the control of the spermatogenesis process.

\section{Acknowledgment}

We are grateful to NIH for the generous gift of FSH.

\section{References}

1. Coniglio JG (1994). Testicular lipids. Progress in Lipid Research, 33: 387-401.

2. Jutte NHPM, Eikvar L, Levy FO \& Hansson V (1985). Metabolism of palmitate in cultured rat Sertoli cells. Journal of Reproduction and Fertility, 73: 497-503.

3. Yount EA \& Harris RA (1982). Ketone body and acetate formation from oleate by isolated rat testicular cells. Archives of Biochemistry and Biophysics, 217: 503-511.

4. Beckman JK \& Coniglio JG (1980). The metabolism of polyunsaturated fatty acids in rat Sertoli and germinal cells. Lipids, 15: 389-394

5. Beckman JK \& Coniglio JG (1979). A comparative study of the lipid composition of isolated rat Sertoli and germinal cells. Lipids, 14: 262-267.

6. Aveldaño MI, Robinson BS, Johnson DW \& Poulos A (1993). Long and very long chain polyunsaturated fatty acids of the $n$ 6 series in rat seminiferous tubules. Journal of Biological Chemistry, 268: 1166311669.

7. Jutte NHPM, Jansen R, Grootegoed JA, Rommerts FFG \& van der Molen $\mathrm{HJ}$ (1982). Regulation of survival of rat pachytene spermatocytes by lactate supply from Sertoli cells. Journal of Reproduction and Fertility, 65: 431-438.

8. Jutte NHPM, Jansen R, Grootegoed JA, Rommerts FFG \& van der Molen HJ (1983). FSH stimulation of the production of pyruvate and lactate cells may be involved in hormonal regulation of spermatogenesis. Journal of Reproduction and Fertility, 68: 219-226.
9. Oonk RB, Grootegoed JA \& van der Molen HJ (1985). Comparison of the effects of insulin and follitropin on glucose metabolism by Sertoli cells from immature rats. Molecular and Cellular Endocrinology, 42: 39-48.

10. Oonk RB \& Grootegoed JA (1987). Identification of insulin receptors on rat Sertoli cells. Molecular and Cellular Endocrinology, 49: 51-62.

11. Hall PF \& Mita M (1984). Influence of follicle-stimulating hormone on glucose transport by cultured Sertoli cells. Biology of Reproduction, 31: 863-869.

12. Dorrington JH \& Fritz MR (1975). Cellular localization of $5 \alpha$-reductase and $3 \alpha$-hydroxy-steroid dehydrogenase in the seminiferous tubule of the rat testes. Endocrinology, 96: 879-889.

13. Chapin RE, Phelps JL, Miller BE \& Gray TJB (1987). Alkaline phosphatase histochemistry discriminates peritubular cells in primary culture. Journal of Andrology, 8: 155-161.

14. Lowry $\mathrm{OH}$, Rosebrough NJ, Farr AL \& Randall RJ (1951). Protein measurement with the Folin phenol reagent. Journal of Biological Chemistry, 193: 265-275.

15. Folch J, Lees M \& Sloone-Stanley GH (1957). A simple method for the isolation and purification of total lipids from animal tissue. Journal of Biological Chemistry, 226: 497-509.

16. Mackall JC, Student AK, Polakis SE \& Lane D (1976). Induction of lipogenesis during differentiation in a preadipocyte cell line. Journal of Biological Chemistry, 251: 6462-6464.
17. Wise LS \& Green H (1979). Participation of one isozyme of cytosolic glycerophosphate dehydrogenase in the adipose conversion of 3T3-cells. Journal of Biological Chemistry, 254: 273-275.

18. Brown J, McLean P \& Greenbaum AL (1966). Influence of thyroxine and luteinizing hormone on some enzymes concerned with lipogenesis in adipose tissue, testis and adrenal gland. Biochemical Journal, 101: 197-203.

19. Borland K, Mita M, Oppenheimer CL, Blinderman LA, Massagué J, Hall PF \& Czech MP (1984). The actions of insulinlike growth factors I and II on cultured Sertoli cells. Endocrinology, 114: 240-246.

20. Buckley BM \& Williamson DH (1977). Origins of blood acetate in the rat. Biochemical Journal, 166: 539-545.

21. Fisher DM \& Coniglio JG (1983). Composition of, and $\left[{ }^{14} \mathrm{C}\right]$ acetate incorporation into, lipids of rat Sertoli cells in culture. Biochimica et Biophysica Acta, 751: 2732.

22. Robinson R \& Fritz IB (1981). Metabolism of glucose by Sertoli cells in culture. Biology of Reproduction, 24: 1032-1041.

23. Collins P \& Lacy D (1969). Studies on the structure and function of mammalian testis. II. Cytological and histochemical observations on the testis of the rat after a single exposure to heat applied for different lengths of time. Proceedings of the Royal Society of London B, 172: 17-38. 